\title{
PARTISIPASI MASYARAKAT DALAM PENGEMBANGAN DESA WISATA AMBENGAN KECAMATAN SUKASADA
}

\author{
Edison Stevanus Frasawi ${ }^{1}$, I Putu Ananda Citra ${ }^{2 *}$
}

Prodi Pendidikan Geografi, Universitas Pendidikan Ganesha, Indonesia

\author{
A R T I C L E I N F O \\ Article history: \\ Received 19 Agustus 2018 \\ Received in revised form \\ 6 November 2018 \\ Accepted 12 November \\ 2018 \\ Available online 30 \\ November 2018

Kata Kunci:
Partisipasi
pengembangan
desa wisata
Keywords:
Participation
development
tou ırism villane

A B S T R A C T

This research aimed (1) to analyzes the level of community participation in the development of Ambengan tourism village (2) Describes the obstacles in the development of Ambengan tourism village. The population in this research is the community of Ambengan Village consisting of a conscious group tours, businesses, and local community leaders. The design used in this study was a descriptive study with data collection method of recording documents were then analyzed using qualitative descriptive analysis. The results showed that (1) the level of community participation in the development of Ambengan tourism village still low at about $90 \%$ in the low category (2) Constraints in the development of Ambengan tourism village is accessibility, infrastructure, accommodation, promotion, and human resources.

\footnotetext{
* Corresponding author.

E-mail addresses: penulis1@undiksha.ac.id (Penulis Pertama), penulis2@undiksha.ac.id (Penulis Kedua)
} 


\section{Pendahuluan}

Pengembangan sektor pariwisata hakekatnya merupakan interkasi antara proses sosial, ekonomi dan industri. Oleh karena itu unsur-unsur yang terlibat di dalam proses tersebut mempunyai fungsi masing-masing. Peran serta masyarakat diharapkan mempunyai andil yang sangat besar dalam proses ini. Untuk itu masyarakat ditempatkan pada posisi meiliki, mengelola, merencanakan, dan memutuskan tentang program yang melibatkan kesejahteraannya. Pembangunan di bidang kepariwisataan mempunyai tujuan akhir untuk meningkatkan pendapatan masyarakat yang pada akhirnya dapat meningkatkan kesejahteraan masyarakat (Zulfanita, 2015).

Menurut (Zakaria, 2014) Pariwisata adalah keseluruhan rangkaian kegiatan yang berhubungan dengan gerakan manusia yang melakukan perjalanan atau persinggahan sementara dari tempat tinggalnya, ke suatu atau beberapa tempat tujuan di luar lingkungan tempat tinggal yang didorong oleh beberapa keperluan. Dorongan kepergiannya adalah karena berbagai kepentingan, baik karena kepentingan ekonomi, sosial, kebudayaan, politik, agama, kesehatan, maupun kepentingan lain seperti karena sekedar ingin tahu, menambah pengalaman ataupun belajar.

Saat ini sektor pariwisata telah menjadi sektor unggulan bagi perekonomian Indonesia. Sektor pariwisata telah ditetapkan sebagai bisnis unggulan nasional yang mampu memacu pertumbuhan ekonomi seperti membuka pariwisata dan membuka peluang usaha hulu-hilir kegiatan pariwisata (Damayanti, 2015). Salah satu prinsip kepariwisataan yang terkandung dalam Undang-Undang No. 10 Tahun 2009 tentang kepariwisataan adalah memberdayakan masyarakat setempat karena masyarakat berhak berperan dalam proses pembangunan kepariwisataan dan berkewajiban menjaga dan melestarikan daya tarik wisata serta membantu terciptanya suasana aman, tertib, bersih, berperilaku santun, dan menjaga kelestarian lingkungan destinasi pariwisata. Kejenuhan terhadap bentuk wisata modern dan ingin kembali merasakan kehidupan di alam pedesaan serta berinteraksi dengan masyarakat dan aktifitas sosial budayanya menyebabkan berkembangnya pariwisata di daerah-daerah pedesaan yang dikemas dalam bentuk desa wisata (Andriyani, 2017).

Terdapat beberapa komponen pengembangan pariwisata yang berkaitan dengan pendekatan perencanaan pariwisata, yaitu: atraksi wisata yang mencakup wisata alam budaya dan atraksi lainnya; akomodasi berupa hotel dan jenis fasilitas lainnya yang berhubungan dengan pelayanan terhadap wisatawan yang menginap; fasilitas dan pelayanan wisata lainnya yang berhubungan dengan kegiatan pariwisata; fasilitas dan layanan transportasi darat, laut, dan udara; infrastruktur lainnya seperti penyediaan air bersih, tenaga listrik, telekomunikasi, dan lain-lain. Wisatawan ingin berkunjung ke area alami, yang dapat menciptakan kegiatan bisnis. Ekowisata kemudian didefinisikan 
sebagai bentuk baru dari perjalanan bertanggung jawab ke area alami dan berpetualang yang dapat menciptakan industri pariwisata (Muntadliroh, 2016).

Industri pariwisata di Indonesia tidak sedikit memberi peran penting bagi perekonomian Indonesia karena dapat memberikan tambahan devisa bagi negara sehingga penerimaan negara meningkat, selain itu dapat menambah lapangan pekerjaan bagi masyarakat sekitar objek wisata misalnya dengan adanya pedagang kecil seperti pedagang makanan ringan dan penjual souvenir yang mengurangi pengangguran dan kemiskinan. pertumbuhan dunia pariwisata Indonesia tidak hanya bisa dilihat dari hal-hal yang berhubungan langsung dengan dunia tersebut, tetapi juga dengan faktor-faktor penting lain seperti kondisi penerimaan masyarakat lokal, keamanan, wilayah dan ekonomi masyarakat (Karim, 2010).

Sadar wisata hendaknya diartikan sebagai pemahaman akan arti dan hakikat pengembangan pariwisata. Lebih jauh lagi menyangkut posisi, misi, dan perannya dalam pembangunan. Sektor ini dicanangkan selain sebagai salah satu sumber penghasil devisa yang cukup andal, juga merupakan sektor yang mampu menyerap tenaga kerja dan mendorong perkembangan investas Masyarakat sadar wisata yang berada di Desa Ambegan, Kecamatan Sukasada, Kabupaten Buleleng seharusnya mengetahui dan meyadari apa yang harus dikerjakan dan juga mengetahui masalah-masalah yang dihadapi untuk membangun sektor pariwisata secara berkelanjutan. Sebagai salah satu industri terbesar di dunia, perkembangan pariwisata diharapkan pariwisata mampu meningkatkan perekonomian sehingga dapat meningkatkan kesejahteraan masyarakat dimana dikembangkannya pariwisata tersebut (Fitriana, n.d.). Sektor ini dicanangkan selain sebagai salah satu sumber penghasil devisa yang cukup andal, juga merupakan sektor yang mampu menyerap tenaga kerja dan mendorong perkembangan investas (Asriandy, 2016).

Wisata air terjun di Kabupaten Buleleng salah satunya berada di Desa Ambengan. Desa Ambengan Khususnya sektor pariwisata merupakan salah satu sektor yang strategis dan potensial untuk dikelola, dikembangkan, dan dipasarkan, mengingat potensi objek wisata yang dimiliki sangat mendukung yaitu wisata air terjun. Untuk itu, adanya partisipasi masyarakat dalam pengembangan pariwisata yang melibatkan semua lapisan masyarakkat, mulai dari kalangan atas sampai kalangan bawa masyarakat biasa. Pengembangan Obyek dan Daya Tarik Wisata (ODTW) yang merupakan penggerak utama sektor kepariwisataan membutuhkan kerjasama seluruh pemangku kepentingan yang terdiri dari masyarakat dan pemerintah, kerjasama langsung dari kalangan usaha maupun dari pihak swasta (Devy, 2017).

Masyarakat akan tertarik untuk mendukung pengembangan dan pembangunan pariwisata apabila mereka telah memahami bahwa mereka akan 
mendapatkan manfaat yang positif. Namun pada kenyataan terjadi tidak seperti yang diharapkan. Tingkat partisipasi dan pemahaman pariwisata masyarakat di Desa Ambengan secara umum masih perlu ditingkatkan. kejadian seperti melayani keperluan wisatawan yang berkunjung, belum menunjukan sikap dan tindakan sebagai tuan rumah.

Berdasarkan latar belakang di atas, maka adapun rumusan masalah dalam penelitian ini adalah (1) bagaimana partisipasi masyarakat dalam pengembangan Desa Wisata Ambengan?, (2) apasaja kendala dalam pengembangan Desa Wisata Ambengan ?. Sesuai dengan rumusan masalah yang dirumuskan maka tujuan dalam penelitian ini yaitu untuk (1) menganalisis tingkat partisipasi masyarakat dalam pengembangan Desa Wisata Ambengan, (2) mendeskripsikan kendala dalam pengembangan Desa Wisata Ambengan.

\section{Metode}

Penelitian ini dirancang sebagai penelitian deskriptif, karena gejala-gejala yang diteliti dalam penelitian sudah ada secara wajar tanpa dibuat oleh peneliti. Data yang dibutuhkan dalam penelitian ini adalah sekunder meliputi data profil Desa Ambengan dan pengelola objek wisata. Metode pengumpulan data yang digunakan yakni metode wawancara, observasi, pencatatan dokumen, dan dokumentasi. Rumusan masalah pertama menggunakan metode deskriptif dengan teknik analisis deskriptif kualitatif melalui penentuan tingkat kelas untuk mengetahui tingkat partisipasi masyarakat. 2) Rumusan masalah kedua menggunakan metode deskriptif dengan teknik analisis kualitatif.

\section{Hasil dan PEmbahasan}

\subsection{Partsipasi Masyarakat dalam Pengembangan Desa Wisata Ambengan}

Pariwisata umumnya merupakan suatu kegiatan yang secara langsung menyentuh dan melibatkan masyarakat dan juga memberikan berbagai manfaat bagi masyarakat di wilayah yang memilki potensi wisata, seperti halnya Desa Wisata Ambengan. Manfaat dari kegitaan pariwisata meliputi beberapa aspek yaitu aspek ekonomi, aspek sosial dan aspek budaya. Manfaat tersebut akan didapatkan secara baik apabila didukung dengan partisipasi masyarakat lokal dalam pengembangan dan pembangunan desa melului sektor pariwisata. 
Pengembangan Desa Wisata Ambengan menuju desa wisata yang unggul merupakan bagian dari penyelenggaraan pariwisata yang berkaitan langsung dengan jasa pelayanan melalui kerjasama dengan berbagai komponen penyelenggara pariwisata yaitu pemerintah, swasta dan masyarakat. Namun kenyataan yang terjadi saat peneliti melakukan survei lapangan, tingkat partisipasi yang berorientasi pada masyarakat lokal di Desa Wisata Ambengan masih minim.

Berdasarkan data tabulasi hasil wawancara menggunakan kriteria penentuan kelas untuk mengukur tingkat partisipasi masyarakat, dapat dikemukakan bahwa sebagian besar masyarakat di Desa Ambengan lebih dominan berada pada tingkat kelas partisipasi rendah. Hal ini dibuktikan dengan kriteria tingkat kelas rendah atau diberi kode angka 1 (satu) pada masing-masing banjar. Angka 1 merupakan tingkat kelas partisipasi rendah, angka 2 merupakan tingkat kelas partisipasi sedang dan angka 3 merupakan tingkat kelas partisipasi tinggi.

Untuk memperjelas uraian diatas, dapat dilakukan perhitungan sebagai berikut.

(1) Menentukan skor terendah dan skor tertinggi dari keseluruhan alternatif jawaban.

Skor tertinggi $=$ (nilai tertinggi $\mathrm{x}$ jumlah pertanyaan $)$

Skor terendah $=$ (nilai terendah $\mathrm{x}$ jumlah pertanyaan $)$

Keterangan :

Nilai tertinggi $=3$, nilai terendah $=1$

Keterangan;

Nilai tertinggi $=3 \times 5=15$

Nilai terendah $=1 \times 5=5$

(2) Menentukan jarak interval

Interval $=($ nilai maksimal - nilai minimal $): 3$

Interval $=15-5: 3$

Interval $=3,3$ atau bulatkan ke atas menjadi 4 .

(3) Menentukan persentase

Untuk menghitung persentase dapat menggunakan rumus $\frac{x}{y} \mathrm{x} 100$.

Keterangan :

$\mathrm{X}=$ Jumlah keseluruhan masing-masing kriteria kelas

$\mathrm{Y}=$ Total keseluruhan kriteria kelas 
Berdasarkan uraian di atas mengenai penentuan skor terendah hingga skor tertinggi, penentuan jarak interval dan penentuan persentase tingkat partisipasi, maka berikut merupakan hasil perhitungan dari uraian tersebut.

Tabel 1

Hasil Penentuan Tingkat Partisipasi

\begin{tabular}{|c|c|c|c|c|c|c|c|c|}
\hline \multirow[t]{2}{*}{ No } & \multirow{2}{*}{$\begin{array}{c}\text { Skala } \\
\text { interval }\end{array}$} & \multirow[t]{2}{*}{ Kategori } & \multicolumn{4}{|c|}{ Banjar } & \multirow[t]{2}{*}{ Jml } & \multirow{2}{*}{$\begin{array}{c}\text { Tingkat } \\
\text { Partisipasi } \\
\text { (\%) }\end{array}$} \\
\hline & & & $\begin{array}{l}\text { Bukit } \\
\text { Balu }\end{array}$ & Jembong & $\begin{array}{c}\text { Pebantena } \\
n\end{array}$ & Ambengan & & \\
\hline 1 & $5-7$ & Rendah & 15 & 10 & 14 & 15 & 54 & 90 \\
\hline 2 & $8-11$ & Sedang & 0 & 4 & 1 & 0 & 5 & 8,3 \\
\hline \multirow[t]{2}{*}{3} & $12-15$ & Tinggi & 0 & 1 & 0 & 0 & 1 & 1,6 \\
\hline & & & Tota & & & & 60 & \\
\hline
\end{tabular}

Sumber: Pengolahan data primer, 2018

Tabel 1 menunjukkan bahwa kategori tingkat kelas rendah berada di Banjar Bukit Balu dan Banjar Ambengan yaitu sebesar 15, sedangkan kategori tingkat kelas berada di Banjar Jembong yaitu sebesar 1. Selain itu, persentase jumlah dari keseluruhan total setiap kelas masing-masing banjar menunjukan bahwa tingkat partisipasi masyarakat di Desa Ambengan masih rendah. Hal ini dibuktikan dengan tingkat partisipasi masyarakat dalam pengembangan desa wisata kategori rendah sebesar 90\%, kategori sedang 8,3\% dan kategori tinggi $1,6 \%$.

Berdasarkan hasil penelitian yang telah diuraikan sebelumnya dapat ketahui bahwa tingkat partisipasi masyakat Desa Ambengan rata-rata masih rendah. Hal ini dibuktikan dengan hasil perhitungan kriteria tingkat kelas berbeda seperti yang telah uraikan pada bab sebelumnya.

Hasil tersebut menunjukan bahwa tingkat partisipasi rendah lebih dominan berada di Banjar Ambengan dan Banjar Bukit Balu, karena kedua Banjar tersebut jaraknya jauh dari objek wisata sehingga berpengaruh terhadap keterlibatan masyarakat dalam pengembangan potensi wisata. Sedangkan masyarakat Banjar Jembong dan Banjar Pebantenan sebagian besar telah menunjukan kepedulian terhadap pengembangan potensi wisata. Partipasi yang dilakukan dalam pengembangan Desa Wisata lebih pada aspek fisik, karena dalam pengembangannya lebih berkontribusi untuk memberikan sumbangan pembangunan secara fisik seperti pembenahan infrastruktur dan penataan objek wisata. Sedangkan aspek non fisik seperti sumbangan pemikiran terkait perencaan pengembangan wisata belum terlihat. Hal ini 
disebabkan oleh rendahnya tingkat pendidikan masyarakat dan sebagian besar masyarakat tidak memiliki kemampuan finansial dan keahlian untuk mengelola atau terlibat langsung dalam kegiatan pariwisata. Sehingga perlu adanya partisipasi aktif masyarakat untuk menjadi tuan rumah yang baik.

Partisipasi masyarakat dalam proses pengembangan Desa Wisata akan terwujud sebagai suatu kegiatan nyata apabila terpenuhi ada tiga faktor utama yang mendukungnya, yaitu (1)kasadaran, (2) kemampuan, dan (3) kesempatan bagi masyarakat untuk berpartisipasi. Dalam hal ini semangat dan kesadaran masyarakat menjadi faktor utama untuk partisipasi masyarakat dalam kegiatan yang mengarah pada pembangunan dan pengembangan desa dengan memanfaatkan potensi atau sumber daya yang terdapat di desa.

Suryo Sakti Hadiwijoyo (2012) meringkas beberapa poinpoincommunity approach bahwa masyarakat lokal harus "dilibatkan", sehingga mereka tidak hanya dapat menikmati keuntungan pariwisata dan selanjutnya mendukung pengembangan pariwisata yang mana masyarakat dapat memberikan pelajaran dan menjelaskan secara lebih rinci mengenai keunikan yang dimiliki seiring dengan pengembangan interest dalam mengembangkan produk pariwisata yang berkesinambungan. Bentuk partisipasi masyarakat juga menjadi esensi bagi pencapaian pariwisata yang berkelanjutan dan bagi realisasi pariwisata yang berkualitas.

Kelompok sadar wisata (Pokdarwis) yang menjadi salah lembaga yang mengelola kegiatan pariwisata di Desa Ambengan seharusnya menjadi wadah bagi partisipasi masyarakat. Sampai saat ini tercatat Desa Ambengan mempunyai dua Pokdarwis yang mengelola objek wisata berbeda yaitu Pokdarwis Jembong dan Pokdarwis Banten Sari. Pokdarwis ini hanya melibatkan beberapa anggota masyarakat dan tidak melibatkan anak-anak muda yang berada dalam organisasi Seka Teruna Teruni (STT), karena sebagian besar memilih untuk menikmati potensi yang ada dan sebagian besar merantau untuk sekolah dan mencari pekerjaan.

\subsection{Kendala Dalam Pengembangan Desa Wisata Ambengan}

Kendala pengembangan pariwisata Desa Ambengan merupakan suatu masalah yang harus diperhatikan dan dikendalikan secara penuh tanggung jawab, baik dari Pemerintah Daerah maupun Pemerintah Desa. Beberapa kendala yang temukan yaitu minimnya kualitas dan kuantitas sumber daya manusia. Berdasarkan hasil wawancara dengan Bapak I Gede Subrata selaku Kepala Desa Ambengan menjelaskan bahwa kendala dalam pengembangan pariwisata yaitu sebagian akses jalan menuju lokasi wisata dalam kondisi rusak 
dan modal dalam pengembangan akomodasi pariwisata seperti hotel atau penginapan belum tersedia.

Hal serupa juga disampaikan oleh Bapak Made Suneka selaku Ketua pengelola objek wisata Air Terjun dan Kolam Renang Jembong menjelaskan bahwa kendala dalam pengembangan potensi wisata Desa Ambengan yaitu akses jalan yang sempit, promosi wisata masih kurang, kualitas sumber daya manusia kurang, serta modal untuk pembangunan sarana dan prasarana pendukung aktivitas pariwisata masih kurang. Selain itu, pernyataan yang sama disampaikan leh Bapak Ketut Nabi selaku bendahara pengelola wisata Air Terjun Kroya, Kembar, Pucuk, dan Blue Lagoon menyatakan bahwa kendala pengembangan potensi wisata yang ada di Desa Ambengan diantaranya kurangnya promosi objek wisata, aksesbilitas jalan tidak memadai, serta sumber daya manusia dan modal masih kurang.

Berdasarkan hasil penelitian, faktor kendala yang menjadi pengahambat dalam pengembangan potensi wisata di Desa Ambengan adalah :

1) Aksesbilitas jalan menuju 5 (lima) lokasi objek wisata, 1 (satu) dalam kondisi baik dan 4 (empat) dalam kondisi rusak. Kondisi jalan menuju objek wisata Air Terjun Jembong dalam kondisi baik, kondisi tersebut didukung oleh jarak antara objek wisata Air Terjun Jembong dengan jalan Kabupaten lebih dekat, sehingga memudahkan proses pembangunan jalan. Sedangkan jalan menuju objek wisata air terjun lainnya tidak mendukung karena jarak antara lokasi objek wisata dengan jalan Kabupaten cukup jauh, sehingga proses pembangunan jalan menuju objek wisata menjadi terhambat. Kondisi jalan yang rusak belum dibenahi oleh Pemerintah Desa Ambengan karena menunggu dana anggrana pembangunan dari Pmerintah Kabupaten.

2) Akomodasiuntuk keperluan wisatawan belum ada. Hal ini disebabkan oleh modal untuk membangun tempat penginapan seperti hotel atau vila masih kurang. Hal ini dikarenakan pendapatan per kapita masyarakat masih rendah karena dilatarbelakangi oleh mata pencaharian masyarakat sebagai petani. Selain itu, masyarakat tidak ingin menjual tanah kepada pihak luar untuk membangun hotel atau vila, sehingga Pemerintah Desa Ambengan tidak menjalin kerja sama dengan pihak luar.

3) Promosi objek wisata masih kurang. Hal ini dikarenakan masyarakat yang terlibat dalam pengelolaan objek wisata belum menguasai teknologi secara baik seperti penggunaan Handphone (HP) sebagai alat untuk mempromosikan objek wisata, sehingga sulit untuk melakukan mempromosikan melalui media sosial seperti Facebook dan Instagram belum tercapai. Promosi yang dilakukan hanya melalui media pamflet yang 
berisikan gambar objek wisata dan ditempat dibeberapa titik di Desa Ambengan. Media promosi berupa pamflet tersebut dibuat oleh Mahasiswa yang melakukan KKN di Desa Ambengan setiap tahun. Sehingga perlu adanya sosialisasi kepada masyakat yang terlibat dalam pengelolaan wisata agar bisa mempromosikan melalui media sosial.

4) Selain ketiga kendala yang telah jelas diatas, sumber daya manusiayang rendah merupakan kendala karenapengetahuan masyarakat masih kurang dalam pengembangan desa wisata, seperti kurangnya penguasaan bahasa asing untuk berkomunikasi dengan wisatawan manca negara. Sedangkan secara kuantitas, jumlah masyarakat yang terlibat dalam pengembangan pariwisata masih sedikit. Keterlibatan hanya kepada masyarakat yang berusia bukan produktif. Hal ini dikarenakan masyarakat usia produktif (anak muda) lebih memilih untuk meninggalkan desa dan merantau untuk mencari pekerjaan ataupun melanjutkan pendidikan.

\section{Simpulan dan Saran}

Berdasarkan hasil penelitian dan pembahasan yang telah diuraikan sebelumnya terkait partisipasi masyarakat dalam pengembangan Desa Wisata Ambengan, dapat disimpulkan bahwa Tingkat partisipasi masyarakat dalam pengembangan pariwisata di Desa Ambengan terlihat masih rendah. Berdasarkan hasil penentuan tingkat partisipasi masyarakat di Desa Ambengan, dapat diktehui bahwa, tingkat partisipasi dalam kategori rendah yaitu 90\%, tingkat partisipasi masyarakat kategori sedang 8,3\% dan tingkat partisipasi kategori tinggi 1,6\%. Rendahnya partisipasi masyarakat dipengeruhi oleh kualitas sumber daya manusia yang rendah. Selain itu, masyarakat yang dalam pengembangan pariwisata memilki kesibukan yang berbeda-beda sehingga fokusnya terbagi-bagi antara sektor pertanian dan sektor pariwisata. Kendala dalam pengembangan Desa Wisata Ambengan diantaranya yaitu (1)Aksesbilitas jalan menuju lokasi objek wisata dalam kondisi rusak (2)Sarana dan prasarana pendukung aktivitas pariwisata tidak memadai (3) Akomodasi perhotelan atau penginapan bagi wisatawan belum ada (4) Promosi objek wisata objek wisata masih kurang (5) Kualitas dan kuantitas sumber daya manusia di Desa Ambengan masih rendah.

Berdasarkan hasil penelitian terkait masalah dalam pengembangan Desa Wisata Ambengan, maka saran yang dikemukakan sebagai berikut (1) Bagi masyarakat Desa Ambengan, bahwa perlu untuk memperhatikan sikap sebagai tuan rumah baik serta memaknai arti penting sebuah konsep desa wisata dengan ikut terlibat dalam pengembangan potensi wisata (2) Bagi pengelola wisata, bahwa perlu memperhatikan dan mengatur sistem pengelolaan objek 
wisata yang berwawasan lingkungan serta memperhatikan kebutuhan para wisatawan seperti sarana dan prasarana pendukung aktivitas pariwisata (3) Bagi Pemerintah Kabupaten Buleleng melalui Dinas Pariwisata sebaiknya memperhatikan mendukung kegiatan pariwisata di desa dengan memanfaatkan potensi wisata sebagai dasar dalam pembangunan dan pengembangan desa menjadi lebih baik.

\section{Ucapan Terimakasih}

Penelitian ini dapat diselesaikan berkat bimbingan dan dukungan dari berbagai pihak. Pada kesempatan ini ucapan terima kasih disampaiakan kepada Rektor Universitas Pendidikan Ganesha, Dekan Fakultas Hukum dan Ilmu Sosial, Ketua Jurusan Pendidikan Geografi sekaligus Pembimbing 1, Pembimbing 2 sekaligus Penguji 2, Pembimbing Akademik, Staf Dosen Jurusan Pendidikan Geografi, Kepala Desa Ambengan, Pengelola wisata di Desa Ambengan, rekan-rekan Afirmasi Pendidikan Tinggi Papua di Singaraja dan rekan-rekan mahasiswa Jurusan Pendidikan Geografi.

\section{Daftar Rujukan}

Andriyani, A. A. istri. (2017). Pemberdayaan Masyarakat Melalui Pengembangan Desa Wisata Dan Implikasinya Terhadap Ketahanan Sosial Budaya Wilayah (Studi Di Desa Wisata Penglipuran Bali). Katahanan Nasional, 23(1), 1-16.

Asriandy, I. (2016). STRATEGI PENGEMBANGAN OBYEK WISATA AIR TERJUN BISSAPU DI KABUPATEN BANTAENG. Hasanuddin.

Damayanti, M. dan L. (2015). STRATEGI KOTA PEKALONGAN DALAM PENGEMBANGAN WISATA KREATIF BERBASIS INDUSTRI BATIK. Pengembangan Kota, 3(2).

Devy, H. A. D. (2017). PENGEMBANGAN OBYEK DAN DAYA TARIK WISATA ALAM SEBAGAI DAERAH TUJUAN WISATA DI KABUPATEN KARANGANYAR. Sosialogi DILEMA, 32(1).

Fitriana, A. N. dkk. (n.d.). PENGEMBANGAN INDUSTRI KREATIF DI KOTA BATU (Studi tentang Industri Kreatif Sektor Kerajinan di Kota Batu). Administrasi Publik, 2(2), 281-286.

Karim, A. B. (2010). PARIWISATA; ANTARA TUNTUTAN INDUSTRI DAN KEARIFAN LOKAL. KKARSA (Jurnal of Social and Islamic Culture), 18(2).

Muntadliroh. (2016). STRATEGI KOMUNIKASI PEMASARAN TERPADU EKOWISATA DI KEBUN RAYA EKA KARYA, BEDUGUL, BALI. JUMPA, 3(1).

Suryo Sakti Hadiwijoyo. (2012). Perencanaan Pariwisata Perdesaan Berbasis Masyarakat ; Sebuah Pendekatan Konsep. Yogyakarta: Graha Ilmu.

Zakaria, F. dan R. D. S. (2014). Konsep Pengembangan Kawasan Desa Wisata di Desa Bandungan 
Jurnal Pendidikan Geografi Undiksha, Vol. 6, No. 3, November 2018, pp. 175-185

Kecamatan Pakong Kabupaten Pamekasan. Teknik Pomits, 3(2).

Zulfanita, B. S. (2015). PENGEMBANGAN DESA WISATA JATIMALANG BERBASIS INDUSTRI KREATIF. ABDIMAS, 19(1). 